\section{"You Can't Argue with Security." \\ The Communication and Practice of Everyday Safeguarding in the Society of Security}

\section{Katharina Eisch-Angus}

\section{Abstract:}

Through ethnographic encounters and interviews in English middle-class neighbourhoods and institutions, such as schools or the police, Katharina Eisch-Angus traces the concepts of 'safety' and 'security' concentrating particularly on their associations with the idea and practice of 'community' and the ways in which they are disseminated within everyday realities. Emerging systems of governmental control gain an irrefutable persuasiveness by coupling the necessity of safeguarding private spheres with public security demands and by referring to a mentality of personal civic responsibility and charity. In everyday narratives and on-going public debates - from issues of health and safety, or neighbourhood crime, to the threat of paedophiles - suggestive fear and everyday experience, reason and absurdity interlock, whilst also opening up space for resistance and alternative decisions.
Keywords: security, community, everyday life, narration, child protection

Katharina Eisch-Angus is a researcher and lecturer at the Chair of European Ethnology at the University of Regensburg and is currently engaged in an ethnographic research project funded by the German Research Foundation: "Sicher im Alltag. Zum Verhältnis von Alltagskommunikation und -erfahrung und gegenwärtigen Sicherheitsdiskursen" ("Safe in Everyday Life. Everyday Communication and Experience and Contemporary Security Discourses").

E-Mail: Katharina.Eisch-Angus@sprachlit.uni-regensburg.de 244

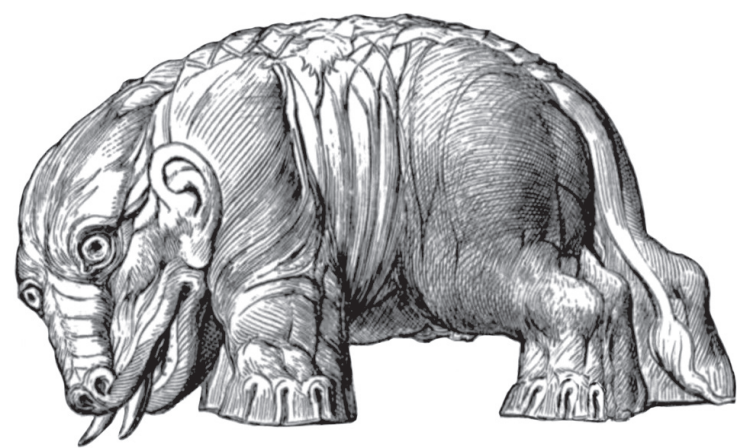




\section{The ethnographic field:}

\section{Community zones between the private and the public}

\begin{abstract}
And we're very much a community round there. [...] we're a community and we sort of say look after each other, but not in the way that we interfere with each other at all [...], we just watch out for each other. My next door neighbour, she has [...] lived there for sixty years. [...] I know you've been talking about security, [...] well if you walk round you'll see, it's a lane, which is like a little private road, [...] it gives you sort of a sense of security, well you sort of walk in there, and [...] the children, we've only got a couple of children there now, but they can [...] go out and play. (Interview 09/07/2009)
\end{abstract}

75-year-old Betty lives in Drunghill, a suburban residential area on the outskirts of a university town, which for the purposes of this article I shall call Lymeston [1]. It is here that I have, in repeated field residencies over four years, inquired into the interpretations and communicative practices associated with the topical keywords of 'safety' and 'security' within the context of the everyday life of members of the British middle class [2]. Within recent discourses of Western countries both terms, with their complementary personal/physical and institutional/societal aspects, join together as a concept, which I shall label as the complex of 'safety/security'. During my fieldwork I presented this theme in various contexts to interlocutors and interview partners including Lymeston neighbourhood residents as well as institutional representatives. It served as a reference point for talking about their everyday views and experience, and as the basis of an interactive ethnographic process that aimed at generating a shared understanding of the meanings and ramifications of 'safety/security' in their daily lives [3].

Pointed towards the theme of everyday security, Betty opened an extensive interview with a description of her social environment. In her construction of an ideal picture of 'community', she referred to the same components as many other respondents: Like her, many of my interlocutors attached their own life-world experience from past and present to deliberations on 'community'. Their narratives mirror the collective understanding and the high social significance of 'community' as a vague, and yet totalising concept of communal living that has developed in Anglophone societies in the post-war years. Simultaneously, a wide range of community-oriented research shows
[1] Names of people and places from the research have been anonymised. Quoted excerpts from interviews and my field notes are reproduced in italics. Translations including quotations from German literature are by Benjamin Tendler and Katharina Eisch-Angus.

[2] Unless other references are given, all information within this article originates from my field investigations in the context of the German Research Foundation project for the Chair of Comparative European Ethnology, University of Regensburg: "Sicher im Alltag. Zum Verhältnis von Alltagskommunikation und -erfahrung und gegenwärtigen Sicherheitsdiskursen" ("Safe in Everyday Life. Everyday Communication and Experience and Contemporary Security Discourses").

[3] With 'safety/security' I attempt to express a semantic polarity as it is covered by the German term 'Sicherheit', which encompasses all aspects of safety and security, in addition to certainty and sureness. Zygmunt Bauman uses the term 'Sicherheit' in order "to lay out a multilevel concept" in Western social life (Aalbers/Rancati 2008, 2759; Bauman 2001). 
that the concept of community has become a consciously shared public value since the 1970s [4]. Following Betty's explanations, 'community' is thought of as taking place in a perceivable and definable space. This space is on the one hand public: People know and recognise each other, children and the elderly alike are looked after. On the other hand, a required level of privacy is in fact preserved. This ambivalent tension between private and public, protection and control runs through the narratives of Drunghill residents. It is not so nosy that you can't have privacy, and at the same time: You've got a small community, you kind of have people watching over [...] what everyone else is doing (interview 10/07/2009): This is how it was expressed by a 19-year-old student when she discussed her understanding of community life in Drunghill - which is for her one of both safety and security.

Wherever interlocutors perceived the 'safety/security' theme of my research as slightly vague or even disconcerting they were able to substantiate my research requests by linking the question of 'safety' to that of 'community'. Thus Barbara, a Drunghill resident in her mid-forties, reformulated the theme at the beginning of our interview: I think [...] it is really community and that sort of thing, safety, security, that you were thinking (interview 26/01/2009). In contemporary Western society, a state of 'security', just like the communal routines of 'everyday life', is equated with 'normality'. However, everyday 'normalities' do not prompt a story to be told so long as they remain uninterrupted and go unchallenged by an event - that is, a disturbance caused by the unpredictable and incalculable. Therefore the stereotypical concepts of 'community', 'community spirit', 'community building', which seem to be ever present in my field, cannot only be associated with 'safety/security', but must also evoke their unsettling flip side of risk and danger. Accordingly, many interviewees contrasted descriptions of their own safe community with stories of smashed windows, break-ins, a police operation or youths stealing petrol and, most of all, accounts of illnesses, accidents or deaths in their surroundings. Considering the ambiguity of 'safety/security', this seems not so much a contradiction, but more of a communicative and narrative necessity. Everyday communication is interwoven with stories and gossip, recollections and renarrations which claim truth as 'a friend of a friend's' true experience, or as a media report, and which find their common thread in linking the spheres of safety and fear, as well as the areas of the familiar and the outer world. In the works of cultural anthropology and narratology [5], such narratives are known as urban or contemporary legends (inter alia Brunvand 1981; Jeggle 1990):
[4] During the last decades the keyword 'community' has come to serve as a receptacle for visions and counterdraft in cultural politics as well as in the social sciences of AngloAmerican stamp, and as a homogenising construct with political and commercial currency. This has prompted equally far-reaching warnings from social scientists as to the hazy suggestiveness of a concept empty of meaning (Day 2006, 1f.). In its overarching semantic outreach 'community' hardly lends itself to translation; for example, the German use of 'Gemeinde', 'Gemeinschaft', 'Gemeinwesen' breaks the concept down into different aspects of collective life that are difficult to grasp and even ideologically contrary.

[5] In German-speaking academia, cultural anthropology ('Kulturanthropologie', 'Europäische Ethnologie') is shorthand for an epistemic community evolving from the critical appropriation of a research tradition formerly known as 'Volkskunde', which since the $19^{\text {th }}$ century focussed on research on 'ordinary people'. 
Their plots play suggestively on the borderline between the plausible, well-known, localised realm of daily life and a vague, otherworldly threat triggering fears by impinging upon one's personal sphere - such as, for example, hooded youths [6], paedophiles or the confidence trickster disguised as a service provider. Urban legends circulate in the limbo between private and public zones. Thus in Dunghill, there is always someone around who can report the most unlikely case of a break-in, a death by fire or asphyxiation, a dangerous infection or a sophisticated fraud at the front door. And even those who would - as occurred repeatedly in my interviews - consider the government's constantly expanding safety regulations crazy or paranoid (inter alia interview 19/01/2009; field diary 02/01/2009) know that associated risk scenarios can always become reality - in which case the most personal and valued is hit: one's body, home, family and social bonding.

In this way, everyday narration follows the ambiguous, and even paradoxical, semiotic and phenomenological signification of 'safety/security': Whilst 'safety/security' can only be expressed by evoking insecurity as its opposite, this in turn eliminates the possibility of a stable state of security. Accordingly, everyday communication serves to maintain awareness of fears and danger and, at the same time, to affirm the safe realm of the community. This communicative association of 'safety/ security', danger and 'community' also became apparent when residents in several neighbourhoods, of varying character, described a neighbour like Chris as a personification of 'community' (inter alia interviews 13/01/2009, 22/01/2009, 26/01/2009, 12/04/2010):

We have one chap who lives along here [...]. He is amazing, because he is always alert. Always knows what's going on, [...] knows everybody and keeps you up to date [...]. If we get on holidays we always tell him. And he'll say: „Oh, I'll keep an eye on things“, and, you'll often find he's popped a little note through the door to say anything that's happened. And you'll feel that Chris will be looking after the place, keeping an eye on things. [...] It's great, an important part of the community in a way, isn't it? (Interview 26/01/2009)

In common with other respondents, Barbara associated the neighbourly keeping an eye on things with community spirit, as well as with 'safety/security' and precaution (interview 26/01/2009). The figure of the watchful neighbour enhances community spirit not only in terms of vigilantly observing activity in the residential street, but, even more, in terms of the comforting presence of neighbours,
[6] In recent years I could observe how the hoody has become one of Britain's top media symbols of everyday threats, as well as of public scaremongering. 
at least in case of emergency, and of communicative exchange in the neighbourhood - having a chat, keeping you up to date, popping a note through the door. In this way, every event, anything that happens, constitutes a possible subject for conversation, as well as a potential threat, the severity of which is actually reduced by its circulation in the neighbourhood's sphere of communication and its inclusion in the pool of shared local knowledge. These constant negotiations take place in the form of chance encounters and seemingly meaningless everyday chats. They symbolically secure the social 'inside' of the community and its borders: They define who one is and what one does, who belongs and who constitutes a threat - such as, for example, the youth, the constantly changing student tenants of former Lymeston family houses, but also the families that refuse to participate in community life. It is the strategies of collective recollection that, through ritual acts of conversation in the street, in the newsagents or on the living room sofa, produce 'community' - and, as a result, 'safety/security'.

My empirical material shows that neighbours of all age groups like to incorporate the communicative village memory of the elderly and old-established residents into their informal chats, which helps to ensure the continuity of the community. Looking to the future, such conversations are a way of tracking everything new and unfamiliar. When, furthermore, neighbours reach in passing a shared understanding of current news items in the media - Polish immigrants, the accident in the Channel Tunnel in 2009 or the recession -, then, fears and global complexity are reduced to the local and the manageable - and to Wendy's letterbox: It is a worrying time now, the 70-year-old explained, [...] you feel all so insecure [...], I just get up in the morning and see what bills come in and what letters come in and go from there (interview 22/01/2009). This quote illustrates Pierre Mayol's deliberations on neighbourhoods as exemplary fields of everyday practice, functioning as spatial-social zones of mediation between 'inside' and 'outside', "between what is the most intimate (the private space of one's lodging) and what is the most unknown (the totality of the city or even, by extension, the rest of the world)" (De Certeau/Giard/Mayol 1998, 11). As a principle, this is by no means new - given that all along it has been the main objective of any community to provide safety and shelter to families and individuals, as well as maintaining the social coherence of the group. However, it is at this communal interface between public and private life that external influences and regimes of power can operate on inner, familial and intimate spheres of lived, everyday experience. This communicative interspace opens the life-world to cultural transformation and, as this 
article suggests, to the realisation of what Michel Foucault described as the 'society of security' (inter alia Foucault 2003).

Foucault embedded his observation of an upcoming 'society of security' in the overarching historical and theoretical framework of 'governmentality', sketching out how disciplinary forms of rule are increasingly complemented and supplanted by subtler techniques of government, which carry their claims to power into every corner of the everyday world. Arguments of 'safety' and 'prevention' aid these new power mechanisms by creating a link to the primary, individual needs, to the safeguarding of life, body and family, by naming and problematising them and short-circuiting them with the security and control requirements of state and society. What Foucault called the 'society of security' is advanced by this specific conceptual alliance of 'safety' and 'security' in the lived-in world, where personal 'safety' is exploited and overpowered by the institutions of 'security'. Foucault theorised governmentality, as well as the notion of the disciplinary society on the basis of powerful historical discourses rather than as empirical findings relating to present-day life realities and everyday practices. Nevertheless, I found a re-reading of his approach helpful for the interpretation of my ethnographic process.

Foucault's argument depends on what he describes as the "milieu": an everyday life-world, which is always already worked, fabricated, organised and planned according to the requirements of "security', and which now becomes a "field of intervention" (Foucault 2007, 21) for the "deployment of mechanisms of security, [...] of a political technique that will be addressed to the milieu" (Foucault 2007, 23). Foucault observed the unfolding of the 'society of security' from the 1970s onward and rooted it in the economically based dealings of liberalism since the $18^{\text {th }}$ century. In union with liberal understandings of freedom, individualism and responsibility, strategies of government became related to the life necessities of the population. With regard to present neoliberal societies, theorists of governmentality such as Tobias Singelnstein and Peer Stolle identify far-reaching and accelerating societal processes of transformation, which have swept the Anglo-American realm in past decades and are more recently reaching continental Europe (Singelnstein/Stolle 2008, 14).

In researching the discourses of 'safety/security' in given local everyday milieus in England, and, by way of comparison, in Germany, I was able to empirically trace these shifts on the micro-social level in numerous and varied manifestations of everyday communication. The initial reactions of my interlocutors to the theme of 'safety/security' indicated that this transformation process, and also 
the role of the UK as a European forerunner in converting to a 'society of security', where inscribed in everyday milieus. Whilst conversational partners in everyday German settings mostly expressed surprise at my anthropological research theme of 'safety/security', English interviewees typically found the subject plausible, one which they were able to associate with community as a lived experience, or with state security issues such as terrorism. At the same time, the British public shares an ambivalent perception of ongoing processes of subjectivation and normalisation associated with keywords such as 'community' and 'safety/security'.

In order to grasp the everyday discourses and practices of the 'security society' not only in the frame of a top-down mechanism of exercising governmental power, I shifted the research perspective towards a subject-oriented, ethnographic view and methodology. I employed a flexible and dialogical process of participant observation, combined with open, narrative interviews, with passive listening and active asking, which allowed me to track and to reflect the changes of everyday life within their situated contexts and from the viewpoints of everyday agents. Interviewees were invited to introduce the themes and interpretations that they themselves found relevant. Rather than predefining and limiting my qualitative research results in favour of quantitative countability and representativity - or, in the words of Clifford Geertz: running "the danger [...] of locking cultural analysis away from its proper object, the informal logic of actual life" (Geertz 1973, 17) - I perceive my cultural fields as webs of meanings and interpretations that unfold in everyday practices as well as in the interactive dialogue of my research encounters (Eisch 2001).

Recorded and reflected in a rigorous methodological procedure, what might be perceived as a seemingly coincidental collection of comments, observations and stories appears as a series of interrelated snapshots of a discursive process expressed on an everyday micro-level. Everyday communication is unavoidably interwoven with the corner stones of collective memory, and with the framework conditions and predominant ideologies of the cultural macro-sphere that are always factored into specific situations. Standpoints, observations and narratives become apparent in juxtapositions and associations within research texts such as fieldnotes and transcripts, for example, in the specific semantic outreach of 'community' or 'security' that occurred in my interviews. The comprehensibility and the ongoing reflection of the practical, interpretative and also emotional involvement of both respondents and researcher in the field remain in the methodological focus of analysis. However, cultural structures can be discerned in repeatedly occurring clusters of themes and their connota- 
tive cross-references within a fixed corpus of ethnographical sources. This incorporates situational fieldnotes and thick descriptions from participant observation, ethnographic conversations as well as interview transcripts. This interactive material is complemented by non-reactive media material such as, amongst others, newspapers, websites, leaflets or administrative safety regulations.

In the following, I will show how seemingly peripheral everyday narrations are a crucial site in the pervasive constitution of the present society of security, and elaborate on the thesis that the everyday milieu is both origin and target of the governmental penetration of present society.

\section{At the heart of everything: Charity, police and performing community safety}

In middle class quarters such as Drunghill - where 'normality' in the context of British mainstream society is defined - the creation of 'safe' and 'secure' communities proceeds not only discursively through the invocation of community spirit, but also through the conscious practices of community building. Witness pensioners Diane und Jacqueline who, in a single breath, mentioned to me their activities linked to the Drunghill Friends of the Surgery group, the local heritage group, the Scrabble group, the organisation of church concerts, of family activities at the Horticultural Society's annual show, as well as the Women's Institute (interview 14/09/2009). This impressive list of community-building practices exemplifies how women are recognised as the organisers and drivers of 'communities'. They provide a lifeline between the families, the generations and the local public sphere. After moving to Drunghill, Barbara, mother of four, missed the mothers' coffee mornings and organisation committees for street parties in the city. Today she is engaged in voluntary work predominantly for the elderly and invalid at an Alzheimer centre and in several church groups, organising talks, a book club, meals on wheels for those who need them - as well as just with the children supporting and helping them (interview 26/01/2009). English middle class women maintain a societal system of provision and care, which differs from Southern and Eastern European private family networks (Roth 2007, 9f.), and also must be distinguished from the idea of the welfare state. Instead, its foundation is in voluntary, yet public charity work: Fundraising activities ranging from pub quizzes and cream teas to sponsored bets and competitions, and to the exchange economy 
of charity shops, are ceaselessly promoted in businesses, schools, churches, clubs, pubs, shops and private gardens. This 'charity society' takes on immense economic dimensions, whereby the organisation and concerns of welfare and neighbourhood initiatives are simultaneously geared towards both a civic responsibility for society as a whole and the needs of one's own community.

Public duty and, at the same time, one's individual commitment to charitable and cultural engagement in family-like cooperation within the community appear as cornerstones of an identity framework that can, on the one hand, be related back to Max Weber's Protestant Ethic: This refers to a pastoral morality in Foucault's sense that shaped a new bourgeois mentality from the $18^{\text {th }}$ century onwards and worked as a motivating force and legitimation for the development of industrialised economy. The pursuit of business and benevolence were ideologically joined as the foundation of a dutiful life for the public good. On the other hand, the entrenchment of today's public life with private charitable practice appears as an anticipation of the entrepreneurial, individualising regimes of subjectivation as outlined by Ulrich Bröckling (Weber 2001; Bröckling 2007). In Britain, with its historical background as a forerunner of industrialisation, pre-existing everyday life-worlds were well suited to provide the starting grounds for the current "restructuring or regulation of the private and public spheres" that Katharina Pühl observes throughout the countries of the West (Pühl 2008 , 117). To some extent, the well-rooted twin-principles of community participation and private responsibility undermine public resistance against the dismantling of the welfare state by turning it back onto the individual with his/her civic duties.

Against this backdrop, my field observations suggest that the centrality of community-building practices in everyday communication feeds into a moral consensus regarding the responsibility of individuals and local institutions that seems to dominate public reflection on the slashing of the welfare state in the UK. On a practical level, British middle class agents, and especially women with their traditional affiliation to families and welfare engagement are assigned an irrefutable, basic responsibility for 'prevention' and 'safety/security' within their communities. 'Safety', as in the need to safeguard our lives and ensure survival can be seen as an anthropological constant that encompasses a priori all issues relating to the body, illness and death. When everyday welfare, with all its familial and intimate aspects, is taken as a central concern of the responsible community, community members as individuals can hardly reject their public and private duties. Moreover, with their strong sense of civic responsibility, my interview partners seemed to take for granted the national signifi- 
cance of their community engagement, and their participation in public campaigns. A communal lunch in Betty's street was prompted by a nationwide appeal promoting community life (interview 09/07/2009), and Jacqueline proudly emphasised the influence of the Women's Institute on government policy concerning issues raised and voted on by local Institutes (interview 14/09/2009).

In Drunghill, such community actions are publicly announced in a showcase prominently placed in the village centre. It is shared with the local neighbourhood policing team, which is introduced with photographic portraits of three policemen and two Police Community Support Officers. In 2009, my inquiries led me directly to two chief organisers of community safety in the Lymeston area: Sergeant Gerald Briggs, the Police Community Safety Officer responsible for the coordination of the Safer Stronger Neighbourhoods Programme, who in turn referred me to his counterpart at the regional council administration, Community Safety Partnership Manager Kirsty Taylor.

Briggs moved seamlessly from his introductory remark community policing has always been there at the heart of British policing to the historical stereotype of the village bobby, a figure that, as he allowed me to confirm, could never exist in Germany: always approachable and permanently visible, the precedent for present-day policing and community work, and, as such, an institution devoted to the continuation of 'primal' British values. These values were also at the core of recent police reforms relating to the primacy of 'prevention'. In accordance with the 1998 Crime and Disorder Act, the police were legally bound by the government to communicate, network and cooperate with communities as well as a range of other agencies, from the emergency and health services to property management, sport clubs or schools (interview 14/12/2009). In Brigg's report, as well as within public community spheres, the Crime and Disorder Act is clearly emphasised as a landmark not only in introducing specific new regimes of the security society, but also in rendering them visible and palpable to all groups and social areas (Hempel/Krasmann/Bröckling 2010).

Under the leadership of the police, all social institutions were to be netted into a single, preventative system administered by the state. In 2009 the council commissioned Kirsty Taylor to coordinate, within a central community safety action plan, around 400 projects, from the reduction of noise nuisance caused by Lymeston nightlife to work with so called antisocial families (interview 09/12/2009). She took special pride in sustaining a network under the sign of 'safety/security', the complexity of which she compared to a map of the London Underground, and which was determined by government policy just as much as it was by communities themselves. Listening to the commu- 
nity and talking to them, as well as to enable them to have a voice (interview 09/12/2009): Both Gerald Briggs and Kirsty Taylor kept repeating this mantra of 'safety/security' work as a service for the communities, reaching far beyond their ostensible obligations to the elderly and vulnerable or to crime protection. Trust and confidence in the community [...] that's all we're measured against (interview 14/12/2009). I should certainly read up about this in the police pledge, Briggs urged me, as published on the police website (as well as in leaflets and local media all over the country) - where I could then find the pledge presented like an institutional, but also personal word of honour: If you are not happy with our service, we'll work with you to resolve things [7].

Briggs's claims for the comprehensiveness of police service and communication reveal an ambivalent tension between the offering of support and the all-encompassing exertion of control: I suppose the object of the exercise is to make sure that we are actually policing the whole community, that we're offering that service [...] to all aspects of the community and there isn't some pockets out there that [...] we're not getting to, we're not communicating with effectively (interview 14/12/2009). The positive rhetoric of empowerment is super-imposed upon the police's assertion of power and control, which is omnipresent in public space - as, for example, in the unprecedented density of CCTV surveillance in Britain [8]. In the interview, and in keeping with the tone of his media and PR work, Gerald Briggs managed to override this tension by absorbing all themes within the perspective of the 'safety/security' rubric, up to and including terrorism, within an emphatic sense of 'us':

'Community' [is] right at the heart of everything we do [...]. From terrorism to daily policing, always, always think 'community', we always do. Because that's what we're here to do, we're here to serve the community. We are the community as well. We live in the community. You know, so it makes total sense doesn't it? [...] And it has come quite a long way from in the old days. But as I say, it's always been there with the village bobby. But we've got teams now, dedicated to this kind of work. And every police officer coming through now, particularly the younger ones in the service know that's at the heart of everything they do. (Interview 14/12/2009)

Nothing and nobody stands outside the 'community', no one stands outside 'safety/security'. In conversation with Gerald Briggs and Kirsty Taylor, "the police character of [...] governmentality" is revealed within the rationale of 'safety/security' (Opitz 2008, 220), whilst its persuasive power in
[7] Community police leaflet for the Lymeston area constabulary (14/04/2010). In July 2008 the Home Secretary published the Green Paper "From the neighbourhood to the national: policing our communities together." [...] The Pledge lists 10 basic standards which the police promise to deliver to the public in England and Wales, and reflects the desire of police forces to connect more successfully with the needs of their communities. http://www.hmic.gov.uk/inspections/pages/policingpledgeinspections.aspx (25/02/2011)

[8] It is apparent in interviews and encounters of lesser privileged or even crime-ridden neighbourhoods of large cities such as Bristol or London that community policing is seen to be of little effect to those who really need it, and that police surveillance is not always experienced as solidarity and protection (inter alia interview 12/04/2010, field diary 02/01/2006). 
society is based on the shared ideology of the civic responsibility of all. Accordingly, Ulrich Bröckling highlights the strategy of 'empowerment' as "a prominent component of contemporary governmentality", the efficacy of which goes hand in hand with "the merging of telos, theory and technology of governance towards self-governance" (Bröckling 2007, 184).

In everyday practices, however, the expansion of police and administrative power through the empowerment and participation of all for security and prevention cuts two ways: Not only are citizens, based on their inherited self-commitment to civic engagement, prepared to accept the shift of public responsibilities onto private shoulders, but, on the same moral basis, they would also place the authorities under their duties. Thus the new empowerment activities under the community policing umbrella, where police leadership and civic responsibility converge, seem to create an exercise field for both individual involvement and insubordination in the name of responsibility and prevention. As an example, British constabularies initiate so-called PACT-meetings (Partners and Communities Together) in local municipalities on the theme of neighbourhood 'safety/security'. In these regular meetings committed locals formally take control. They list and prioritise their concerns, which the representatives of the police, local authority and other administrative bodies in attendance must then deal with accountably in the following weeks. I experienced one such meeting in April 2010 in a church hall in Lymeston. There I found myself, as a German, stunned by the marked contrast between the ritualised alternation of teamwork and discussion, and formulaic communality on the one hand, and the harsh tone in which police and elected politicians were addressed on the other. Prickly interjections such as I live here, I am eighty years old or it is about my safety seemed to assume some kind of debt of the authorities, based on the provenance and experience of local citizens (field diary 14/04/2010). In this charged atmosphere, even the very means of survival were called into question due to the incompetence of the police and politicians. I was astonished by the weighting of topics addressed, which matched exactly the typical top priorities at PACT meetings, as outlined by Sergeant Briggs in the interview: Not that many are to do with real crime as such like burglaries, car crime and stuff like that. There's quite a few antisocial behaviourissues, [...] car speeding issues in the street, and then you get things like dog fouling, litter, cleaning (interview 14/12/2009). PACT meeting priorities are interchangeable and never finally resolvable; however they serve, under the safety dispositive, as a communicative and performative manifestation of one's civic duty and of 'community' - simply by flagging up all those 
well established topoi of cleanliness, cleansing and exclusion, from dog dirt to antisocial persons, and more often than not youths.

However, although the concerns of 'community', 'prevention' and 'safety/security' seem to be reduced to the level of banality, they are by no means inconsequential. This was illustrated by Sgt. Briggs' ambition to establish at the third safest university in the country a Student Watch project, whereby 'safety/security' was to be accomplished with the help of trained student volunteers, in parallel to the Neighbourhood Watch scheme that has operated in British residential areas since 1982. His reasoning seemed astonishing: We're not doing it because there's a real problem of students becoming victims of crime, that's not what it's about. Rather, it was about advertising the university to the public and particularly to the parents funding their children's studies: This university has a sense of community. Students are interested in looking after each other. Independently of any factual occurrence, an indisputable value was attached to 'safety/security' as well as to 'community'.

At this point Ernesto Laclau's theory of the 'empty signifiers' offers some further paths for interpretation (Laclau 1996). Because of their universally accepted validity, combined with a wide semantic scope, terminologies of order, of 'community' as well as 'safety/security' can indiscriminately encompass everything and pull everything into their ambit. Yet, in order to maintain this totality, they need to exclude anything that might claim value and difference outside of this sphere of dominance: The result is a system of signification that cannot express anything - it turns empty [9]. The empty signifier, like the claim of 'safety/security', is total and always right: We have to create safety, said Gerald Briggs, you can't argue with that (interview 14/12/2009) [10].

In British society 'safety/security' and 'prevention' are well understood as values and ends in themselves. Carrying the moral weight of charity commitment and private responsibility, they make a convincing case for an individualised, market-oriented university and pave the way for the withdrawal of the state from society. However, at the same time, the 'empty' terminology of 'safety/ security' must constantly be loaded with life-world experience and legitimised by the real possibility that a student's laptop is actually stolen or an elderly resident injured by a speeding driver, a pothole, broken glass or youths on the rampage. On a level of semantic creation of sense and meaning, this leads to an ongoing tension between the generalisation and blurring of the contents of an overarching concept of 'safety/security' and the highlighting of concrete 'cases' from 'real life' in order to give evidence to the entire semiotic system of the empty signifier. Roland Barthes described this
[9] Ernesto Laclau uses the semiotic mechanism of the 'empty signifier' to explain how political agitation and social movements function: Culture and signification come about through differentiation between signifying entities. When the whole system is subordinated to one single, abstract message (such as ideological messages meant to temporarily unify and enclose all opposing groups in a situation of protest) these differences break down into chains of equivalential terms, whereas any signification with positive, contradictory meaning will be excluded as non-existent, or as pure negativity. The result will then be an aporetic state (which to a great extent conforms with the paradox of the term 'security' that can only claim validity by its power to exclude danger and risk, but is, at the same time, constituted and made visible only by dangerous occurrences). If the meaning of a signifier or of a signifying system can no longer be defined by its difference from other signs and contents, it is emptied whilst the inclusion of all other signs and messages into the system of the empty signifier still produces a universal claim to power (Laclau 1996).

[10] This quote resonates with the one used in the title of this essay, the words of a passenger I overheard at Cardiff Airport (field diary 07/01/2007). 
oscillation of the signifier between its empty, ideological omni-signification and its potential content rooted in reality as a functional principle of the 'mythologies' of everyday life (Barthes 1957/2000).

Thus he refers us back to the significance of everyday narration: Each story told about events of insecurity and adversity may confirm the rightness of the comprehensive ideological and organisational system of 'safety/security'. Not only does it underline the capability of the police and other institutional agencies to create safety, but it will also keep the emotional implications of threat and fear in circulation. As such, the insecurities of the security society - the "culture of danger" as Foucault described the mechanisms of ubiquitous incitement of fears (Foucault 2008, 67) - appear to be caused less by our rational knowledge of risks and probability than implemented suggestively: They can be seen as a product of narrative disseminated through everyday communicative practices of symbolic social safeguarding. Aided by the narrative qualities of danger, in advertising, newspapers, advice booklets or broadcasts, an empty, yet convincing everyday rationale of 'prevention' and 'safety' is nourished within local life-worlds and woven into an overarching rhetoric of 'safety/security' in the UK as well as in other parts of the Western world. It justifies an explosive growth in institutional techniques of intervention and control, which are in fact neither able nor intended to fundamentally eliminate the danger invoked.

\section{Paedo-mania: The paedophile debate and the paradox of security}

The 'security' argument cannot be lost - because its promises can never be kept. The contradictory project of modernity to render accident and disaster, by their very nature uncontrollable and outside the course of normal experience, 'normal', predictable and calculable is the motor of the governmental 'society of security'. Claiming to create 'security' and simultaneously problematising ever more new risks generates its inherent paradox. [M]aking the communities [...] feel safe and be safe is the promise, stated side by side with the permanent spelling out of risks relating to burglars, fire and other threats to house and home [11]. This aporetic constitution of the security society is also manifest in the ambivalence of my interlocutors. By way of example, 80-year-old Beatrice gladly confirmed how safe she feels in her neighbourhood, but also complained that Neighbourhood Watch briefings cause her to worry (field diary 21/03/2008), and Barbara described her surroundings as
[11] Community police leaflet for the Lymeston area constabulary (14/04/2010). 
incredibly safe but does not allow her 12-year-old daughter to walk around the village alone. She would prefer not to talk to youths of a certain appearance - because of today's knife culture (interview 26/01/2009).

This contradictory discursive foundation of everyday practice not only traps people within the compulsive regulations and mechanisms of 'safety/security'. It can, just as well, work the contrary way by drawing attention to usually unquestioned everyday routines, bringing the insufficiency and meaninglessness of formal safety requirements to the surface. Especially in situations of personal crisis or death - when the firm ground of everyday normality cracks - the claim to rationality of the security system produces a feeling of irrationality. When visiting a dying relative in the hospital, the pithy STOP sign that warns visitors upon entry because you could be bringing infection feels equally as impertinent and absurd (field diary 10/01/2009). In an interview, Lydia, a teacher, linked attitudes towards 'safety/security', and perceptions of reality and irreality to personal experience of danger: People who live through violent times are less insecure [...] If you think about the war generation, who lived through the Blitz and lived through bombing here and came out of it - you know, it's more real to them (interview 08/01/2009). Similarly, when interlocutors recalled existential experiences within their own lives or personal spheres, the emotional presence of these experiences would suspend administrative security guidelines as being fairly out of place. This is apparent, for example, in the accounts of ex-police woman Sibylla who got caught on the beat in a one-to-one showdown with a violent resident (interview 09/04/2007), and of Beatrice who experienced a house going up in flames in her residential lane due to an electrical surge (interview 09/07/2009), or in Betty's concern for a neighbour whose young sister had recently been diagnosed with a terminal illness (interview 09/07/2009). In recounting these situations of insecurity and shock the otherwise threatening medial and institutional scenarios of crimes, accidents and illness no longer seemed to play a role; the emotional reality of personal experience appeared to expose their empty, narrative power of suggestion and render them powerless.

The narrative exchange of experience in everyday life - as mirrored in the interview situation points towards another essential function of neighbourhood chats: Besides fuelling the perpetuation of collective fears, they can also counteract this effect, and allow people to communally defy the discursive thrust of 'safety/security'. Neighbours know well that the collective and experience-based exchange and support in the case of existential crises can hardly be replaced by institutional provi- 
dence. Moreover, everyday narratives seem to carry an overall understanding that the promises of security, as empty signifiers, deny the experiences of real life in their unpredictability - whilst they can still hit us daily at every corner.

Against this background it is less surprising that especially older people - themselves among the most vulnerable - never tire of contrasting their own, unsupervised childhood outdoors with the restrictions imposed on children today. Within today's security dispositive, these childhoods would appear as highly risky - yet they are portrayed as a loss for society. And we never needed it!, Wendy argued against the safety requirements enacted by a young family, who moved into her remote residential street: They're not open enough, [...] when these people moved up they were saying about lights and things and you know security and things like that. It is above all in this way that older people counter new demands of 'safety/security' with their own life experience. When her new neighbours erected a high fence as a visual shield for the safety of the children, Wendy experienced this as a personal and collective threat and an affront to her lifelong experience of safeguarding neighbourhoods: This is the death of community, she states (interview 22/01/2009). From a pre-governmental perspective, whereby misfortune may come to pass but cannot be predicted, the openness of social relations, with doors left unlocked and chats over the garden fence, stands for 'safety' and 'security' - an openness which is now inverted into a preventative, universal suspicion. In the everyday worlds of families and communities, 'safety/security' reveals its ambivalence and perspectivity: One person's safety is another person's insecurity.

It is not only in the Drunghill neighbourhood that the discourse of prevention and public responsibility is increasingly contested with reference to children. Barbara experiences this daily as a moral dilemma between the wish to follow her own common sense as a mother and the need to bow to external pressures:

I sometimes think that it's a shame that we do feel we've got to protect them so much, that we have to drive them everywhere. That you always feel guilty [...], I sometimes find some of my friends would be a bit critical or would look at me suspiciously for letting [my daughter] walk up to school [...]. If you're not careful you can get sort of things out of proportion. [...] they probably never get exposure to learning those basic skills of self preservation. (Interview 26/01/2009) 
In British local media and community conversation congested thoroughfares caused by parents on the school run is a perennial topic in which road safety for children becomes increasingly entangled with the danger of paedophile kidnappers. When, in a parents' circular, Barbara is warned about a dubious stranger snooping around outside the school (interview 26/01/2009), then parents, schools and police can escape neither the seriousness of the situation nor the numinous suggestive power possessed by the figure of the paedophile, who, nonetheless, appears to have more to do with the proverbial bogie man, spooky car driver or vanished hitchhiker of the urban legends of the 1970 s than with the reality and probability of child abuse (Brunvand 1981).

Yet hardly any topic in the contemporary, everyday British context seems to exert greater influence than the threat of child sex abuse. No other topic is capable of more effectively and subtly focussing societal fears and unsettling notions of the familiar and, at the same time, integrating them within the compulsions of the 'safety/security' discourse. In the midst of all of this the institutions dealing with children and youths have been exposed since the 1990 s to an immense psychological pressure, proportional to the level of responsibility they have had to take on, under the scrutiny of both the government and the public. As a result, and also due to bureaucratisation and standardised methods of risk assessment, employees in these institutions must reckon with an increased risk of mistakes and misjudgement (Littlechild 2009). The fear amongst teachers and other staff in schools in the face of legal liability and, even more so, press coverage clearly corresponds to the readiness of parents and local newspapers to pillory schools for discrimination or negligence involving children.

When I tried to contact schools (which I naively perceived as open hubs for generations and communities alike) with a view to conducting research interviews, I was not conscious of this charged atmosphere, marked by schools barricaded against paedophile intruders with locked entrances, CCTV cameras and intercom. Indeed, from my German perspective, bullying and violent youths, if not shooting sprees, are far more likely to be thought of as dangers at school. Only through the defensive reactions of several school representatives to my requests, I gradually realised that I, too, was classified as a 'security risk'. Of the schools I approached, only one headmistress granted me an appointment, cautiously asked about my use of names and other information and patiently explained safety rules in British schools and above all the CRB check (Criminal Records Bureau), a kind of police certificate of conduct that even parents regularly involved in school activities are required to obtain[12].
[12] The Criminal Records Bureau was introduced as an executive government agency in 2002 to check any persons wishing to work or engage in general activities with children or vulnerable adults for previous convictions or conspicuities known to the police. 
For obvious reasons, she said vaguely but impregnably, and then explained: We had this case, a caretaker had been left alone with two girls, who he murdered. The case in question took place in 2002 in the small English town of Soham and was extensively reported by local and national media outlets over several months. With reference to a media-constructed $w e$ - a national community - the headmistress accepted a responsibility, derived from this double-murder, as conveyed by the press eight years ago. After implying with inescapable common sense that I might be capable of spontaneous child murder, she then added to her stereotypical sentence It is for the safety of the children a hesitant: But sometimes it goes too far. In the end she evaded the dilemma by referring me to her superior authority (field diary 27/01/2009). Despite being authorised to make an autonomous decision, the headmistress passed the ball on in a game in which the responsibility of the individual is accepted and circulated, only to finally disappear within the loop of a generalised, empty responsibility of all. The irrefutable concern for children consolidates a power structure that is continuously reproduced by the representatives of public and semi-public services, and, at the same time, targets them as both responsible and vulnerable individuals. In turning to the authorities, the headmistress first and foremost secured her own position in relation to the parents, the media, her professional network and her own personal feeling of responsibility in line with the requirements of the security dispositive.

Yet the question remains as to why she did not simply send me away in the first place. Did she take a chance to draw the attention of the authorities to her commendable 'safety/security' consciousness - or did she sense that this German outsider with her unusual, subject-centred research could be an ally in her own ambivalent situation? In the middle of the conversation she noted that the whole process coincided with the object of my study - which allowed her to step back and take another look at the rather absurd side of the 'safety/security' rationale.

In the same year, the very kind of ambivalence that was apparent throughout my research led to a discursive explosion in the public debate about child abuse - this, of all things, in a society that takes child protection as an official societal task: Child protection, fire control, infection management (...) those basic things everybody has to do, as the hospital employee Linda listed the themes of regular inservice training (field diary 09/12/2009). During the $11^{\text {th }}$ and $12^{\text {th }}$ September 2009, government plans to launch a new, more rigorous vetting scheme for all those wishing to work with children and vulnerable adults and to establish a new Independent Safeguarding Authority circulated in the media [13].
[13] Take, for example, the following headlines from three national media outlets with very different, contrary orientations: Checks on children's clubs drivers. In: $B B C$ News online, 11/09/2009. http://news.bbc.co.uk/2/hi/8249020. $\operatorname{stm}$ (18/01/2011). - Now big brother targets helpful parents. In: Daily Mail, 11/09/2009, 1. - Database for children needs rethink, says Soham chief. In: The Daily Telegraph, 12/09/2009, 1. 
Compulsory registration with the ISA would also affect private persons regularly engaged in clubs and other organisations, assisting in areas such as care or providing transport. All individuals with any police records would be barred. Purely private arrangements would not be affected.

In the ensuing period, wherever I discussed the object of my study or sought interviews, I was struck by the indignation prompted by the screenings related to this vetting scheme: We are disgusted protested female pensioners at a church painting group in Drunghill (field diary 16/09/2009). One in four would be hit, this stereotype quickly spread, stressing the vast number of citizens affected - who would even have to pay for the checks. We had 30 years of being made insecure, a folk singing club member in a small, neighbouring town remarked, linking the vetting scheme to longterm political scare tactics and intimidation dating back to Margret Thatcher's spell in office (field diary 15/09/2009). My interlocutors, in conformity with most media commentaries, applied the same epithets throughout: madness, crazy, ludicrous, ridiculous, this is a joke, this is a mockery... to express disgust, helplessness and protest, and, above all, the feeling that reason, normality and comprehensibility had been banished. The contradictions inherent in this tightened regime of prevention and control were made obvious. The new scheme would neither have stopped the Soham murders, nor would it capture potential perpetrators without previous convictions, nor prevent the vast majority of child abuse, which is statistically carried out within family circles. At the very most, the new regulations could have an effect where long term bonds of trust with children in public and semi-public everyday settings were established [14].

However, the ineffectiveness of the proposed measurements does not sufficiently explain what enabled people, and above all older women, to emotionally override horror stories of abused and murdered children, or the heated debate on the housing of convicted sex criminals conducted in the media for years. The alarm over the fact that under the security regime everyone is a suspect, everyone is guilty not only exposes the core of 'prevention' that fundamentally affects the presumption of innocence as a foundation of the civil society (Opitz 2008, 223). The alarm runs deeper still, as it goes to the heart of the governmental system of empowerment and control. The Independent Safeguarding Authority goes some way towards disenchanting the middle class ideals of family and community as strongholds of safety. Moreover, as it turns against, of all people, the engaged volunteers who actually sustain the social 'safety net', it reveals the governmental instrumentalisation of both family and community. It is first and foremost this attack on the very fabric of an identity based
[14] For professional advice on the scientific backgrounds and public implications of current discussions of child abuse I am indebted to Barbara Wittel-Fischer (Pro Familia, Münster). 
on shared civic responsibility that could spark protest: People would mutually support one another just like normal, fumed Linda, and then find themselves colliding with the law. This destroys the community (field diary 09/12/2009).

In the process, protest and feelings of degradation may develop in one of two ways: If everyone is, potentially, an offender, everyone might therefore also be a victim, a child or vulnerable adult. As Mary Wakefield ironically remarked in the Independent in August 2009: So we all need a CRB check to look after ourselves - because, ultimately, no one can succeed in life without the help of others [15]. This is reminiscent of the community safety officials Gerald Briggs and Kirsty Taylor, who both firmly emphasised in accordance with their community work guidelines that citizens should never be perceived as complainers but rather as victims (interviews and field diaries 09/12/2009, 14/12/2009). Given the great willingness and positive endorsement in English middle class society to complain and to stand up for one's individual and communal rights, this may well be read as a kind of cloaked institutional revenge upon the all too capable citizen, a running exchange of blows under the cover of the duty to serve on the one hand, and civil responsibility on the other.

In 2009, both sides in the child protection debate appealed to reason and responsibility and yet, both sides also drew on the suggestive facticity of case stories. As such, the Soham double-murder was countered by examples where the probing of private lives or the criminalisation of neighbourhood childcare had proved unlawful and absurdly counterproductive - whilst all efforts of the authorities to explain the actual plans went unheeded: Narrative insecurity and fear never differentiate. Upon becoming caught up in its own contradictions, the regime of 'safety/security' had now distinctly lost credibility. In this moment the everyday naturalisation of control and the governmental penetration of privacy, the instrumentalisation of emotion, family and intimacy became apparent and, as such, could be addressed by the public. The prospect that the protection of the intimacy of children could be turned against the intimate sphere of the individual drew public attention to the reality (or the irreality) of the regimes of 'safety/security' and 'prevention' in a particularly unsettling manner.

The public scandalisation of the implementation of the Safeguarding Authority resonates with a prediction Foucault expressed as early as 1979, referring to the function of children, sexuality and sexual violence for the purposes of bringing new technologies of control into operation: "We're going to have a society of dangers, with, on the one side, those who are in danger, and on the other, those who are dangerous. And sexuality will no longer be a kind of behavior hedged in by precise prohi-
[15] Wakefield, M.: I want to help but I'm not allowed to. In: The International Independent, 08/08/2009, 15. 
bitions, but a kind of roaming danger, a sort of omnipresent phantom [...]. Sexuality will become a threat in all social relations, in all relations between members of different age groups, in all relations between individuals. It is on this shadow, this phantom, this fear that the authorities would try to get a grip [...]" (Foucault 1996, 270). The attachment of sexuality to power and fear and the institutionalised suspicion against all spell the end of social relationships, as many respondents in my field know. Above all older women and men expressed the reservation that children shielded in the proposed way would no longer learn the practices of safeguarding and streetwise behaviour in public space, and that 'normal' relationships, free of fear, with children would no longer be possible. I am sorry for the men, women said (field diaries 15/09/2009, 09/12/2009), and: No one would dare to speak to a child looking lost or upset on the street any more (field diaries 15/09/2009, 09/12/2009, 17/12/2009, 28/12/2009; interview 11/o9/2009) [16].

Overall, my empirical study into everyday discourse and practices was guided by the objective to question how "the opposing forces that challenge the programmes of governing and self-governing [...] enter into their construction and modification" (Bröckling 2007, 40). That is, in the British case, how England's political culture and the historical empowerment of the responsible and self-responsible subject drive, on the level of the everyday, the implementation of neoliberal power structures. Methodologically, I have illustrated in which way an ethnographic everyday approach can open the view towards existing leeway for oppositional, common sense practice. In this case-study, I have highlighted oppositional practices for example of women and older people; through the lens of everyday communication, tendencies contrary to the overarching 'security/safety' complex became visible. I have outlined the assertive force of personal experiences, which are able to bring the exaggerated compulsions of 'safety/security' governance back down to earth and to call to a halt the cycles of contradiction and paradox that drive the safety and prevention systems to increasingly bizarre heights.

In the end it became visible that it was the experience of the absurd that dominated the resistance of everyday culture and common sense, as illustrated by attributions of madness or paedo-mania [17]. Albert Camus and Shlomo Giora Shoham regarded the perception of the break-down of normality, the emptying out of collective systems of meaning, and the sudden eruption of the unreal as the modern individual's authentic mode of experience (Camus 2005; Shoham 2006). Equally, in the context of the neoliberal system, the everyday individual can at least, in experiencing and reflecting on the absurd, pause and access a moment of stillness and a fleeting glance towards an alternative.
[16] By way of contrast, the German criminal record registration system takes a lot of the heat out of the problematisation, fiercely contested in the British debate, of preventative control. A German debate about institutional child abuse broke out at roughly the same time. Compared to the British debate, it lacks the critical reflection on the ambivalence of power relations and empowerment, and on the potential of both to be reversed and exploited.

[17] Revealed: The people's guide to common sense. In: The Independent, 02/01/2011, 9. 
The British 'paedophile' discussion remained, at the end of 2010, unresolved. On the Independent Safeguarding Authority's website, the new coalition government resorts to a paradoxical return to common sense while confirming the intensification of preventative control: the Government set out its aim to 'review the criminal records and vetting and barring regime and scale it back to common sense levels', however: Whilst implementation is halted whilst the review is undertaken, the safeguarding regulations introduced in October 2009 continue to apply [18].

\section{Bibliography}

Aalbers, M. B./Rancati, S. (2008) Feeling Insecure in Large Housing Estates: Tackling Unsicherheit in the Risk Society. In: Urban Studies 45 (13): 2735-2757.

Barthes, R. (1957/32000) Mythologies. London: Routledge.

Bauman, Z. (2001) Community: Seeking Safety in an Insecure World. Cambridge: Polity.

Bausinger, H. (1958) Strukturen alltäglichen Erzählens [Structures of Everyday Narrative]. In: Fabula 1: 239-254.

Bröckling, U. (2007) Das unternehmerische Selbst. Soziologie einer Subjektivierungsform. Frankfurt a. M.: Suhrkamp.

Brunvand, J. H. (1981) The Vanishing Hitchhiker. New York: Norton.

Bruner, E. M. (1986) Ethnography as Narrative. In: Turner, V. E./Bruner, E. (eds.) The Anthropology of Experience. Urbana/Chicago: University of Illinois Press.

Camus, A. (2005) The Myth of Sisyphus. London: Penguin.

Day, G. (2006) Community and Everyday Life. London/New York: Routledge.

De Certeau, M./Giard, L./Mayol, P. (1998) The Practice of Everyday Life. Vol. 2: Living and Cooking. Minneapolis/London: University of Minnesota Press.

Eisch, K. (2001) Erkundungen und Zugänge I: Feldforschung. Wie man zu Material kommt [Explorations And Approaches I: Field Research. How to Come by Material]. In: Löffler, K. (ed.)
[18] http://www.isa-gov.org (30/12/2010). 
Dazwischen. Zur Spezifik der Empirien in der Volkskunde. Vienna: Institute of European Ethnology of the University of Vienna.

Eisch-Angus, K. (2007) Psychoanalyse und Semiotik im Sicherheits-Netz: Eine ethnografische Verwirrung und methodische Verknüpfung [Psychoanalysis and Semiotics in the Safety Net. An Ethnographic Confusion and Methodical Connection]. In: Timm, E./Katschnig-Fasch, E. (eds.) Kulturanalyse - Psychoanalyse - Sozialforschung. Positionen, Verbindungen und Perspektiven. Vienna: The Austrian Museum of Folklore.

Eisch-Angus, K. (2011) Tägliche Verunsicherung: Übersetzungsprozesse zwischen Alltagserfahrung und neuen Sicherheitsdiskursen [Daily Insecurity. Translation Processes between Everyday Experience and New Security Discourses]. In: Keinz, A./Schönberger, K./Wolff, V. (eds.) Kulturelle Übersetzungen. Berlin: Reimer.

Foucault, M. (1996) The Danger of Child Sexuality. In: Foucault, M./Lotringer, S. Foucault Live (Interviews, 1961-1984). New York: Columbia University.

Foucault, M. (2003) Die Sicherheit und der Staat [Security and the State]. In: Foucault, M. Schriften / Dits et Ecrits. Vol. 3 1976-1979. Frankfurt a. M.: Suhrkamp.

Foucault, M. (2007) Security, Territory, Population. Lectures at the Collège de France 1977-1978. Basingstoke: Palgrave Macmillan.

Foucault, M. (2008) The Birth of Biopolitics: Lectures at the Collège de France 1978-1979. Basingstoke: Palgrave Macmillan.

Geertz, C. (1973) The Interpretation of Cultures. New York: Basic Books.

Hempel, L./Krasmann, S./Bröckling, U. (2010) Sichtbarkeitsregime. Überwachung, Sicherheit und Privatheit im 21. Jahrhundert. Wiesbaden: VS Verlag.

Jeggle, U. (1990) Tödliche Gefahren. Ängste und ihre Bewältigung in der Sage [Deadly Dangers. Coping with Fears in Legends]. In: Zeitschrift für Volkskunde 86 (1): 53-66.

Laclau, E. (1996) ,Why do Empty Signifiers Matter to Politics?‘ In: Emancipation(s). London: Verso.

Lemke, T. (2000) Neoliberalismus, Staat und Selbsttechnologien. Ein kritischer Überblick über die governmentality studies [Neoliberalism, State and Self-Technologies. A Critical Overview over Governmentality Studies]. In: Politische Vierteljahresschrift 41 (1): 31-47.

Littlechild, B. (2009) Child Protection Social Work: Risks of Fears and Fears of Risks - Impossible 
Tasks from Impossible Goals? In: Denney, D. (ed.) Living in Dangerous Times. Fear, Insecurity, Risk and Social Policy. Chichester: Wiley.

Pühl, K. (2008) Zur Ent-Sicherung von Geschlechterverhältnissen, Wohlfahrtsstaat und Sozialpolitik. Gouvernementalität der Entgarantierung und Prekarisierung [About the De-Securisation of Gender Relations, Welfare State and Social Politics. The Governmentality of De-Garanteeing and Precarisation]. In: Purtschert, P./Meyer, K./Winter, Y. (eds.) Gouvernementalität und Sicherheit. Zeitdiagnostische Beiträge im Anschluss an Foucault. Bielefeld: transcript.

Opitz, S. (2008) Zwischen Sicherheitsdispositiven und Securization: Zur Analytik illiberaler Gouvernementalität [Between Security Dispositives and Securization: Analytics of Illiberal Governmentality]. In: Purtschert, P./Meyer, K./Winter, Y. (eds.) Gouvernementalität und Sicherheit. Zeitdiagnostische Beiträge im Anschluss an Foucault. Bielefeld: transcript.

Purtschert, P./Meyer, K./Winter, Y. (2008) (eds.) Gouvernementalität und Sicherheit. Zeitdiagnostische Beiträge im Anschluss an Foucault. Bielefeld: transcript.

Roth K. (2007) Trust, Networks and Social Capital in the Transformation Countries. In: Roth, K. (ed.) Soziale Netzwerke und soziales Vertrauen in den Transformationsländern. Ethnologische und soziologische Untersuchungen. - Social Networks and Social Trust in the Transformation Countries. Ethnological and Sociological Studies. Münster/Berlin/Hamburg/London/Wien/ Zürich: LIT-Verlag.

Shoham, S. G. (2006) Society and the Absurd. London: Blackwell.

Singelnstein, T./Stolle, P. (2008) Die Sicherheitsgesellschaft. Soziale Kontrolle im 21. Jahrhundert. Wiesbaden: VS-Verlag.

Weber, M. (32001) The Protestant Ethics and the Spirit of Capitalism. Los Angeles: Roxbury.

Wolf, M. A./Rathmayr, B./Peskoller, H. (2009) (eds.) Konglomerationen - Produktion von Sicherheit im Alltag. Theorien und Forschungsskizzen. Bielefeld: transcript. 